\title{
NEW READINGS OF THE AMERICAN NOVEL
}

Narrative Theory and its Application 


\section{NEW READINGS \\ OF THE \\ AMERICAN NOVEL}

Narrative Theory and its Application

Peter Messent

Macmillan Education 
ISBN 978-0-333-43797-1 ISBN 978-1-349-21117-3 (eBook)

DOI 10.1007/978-1-349-21117-3

(C) Peter Messent 1990

Softcover reprint of the hardcover 1st edition 1990 978-0-333-43796-4

All rights reserved. For information, write:

Scholarly and Reference Division

St. Martin's Press, Inc., 175 Fifth Avenue,

New York, N.Y. 10010

First published in the United States of America in 1990

ISBN 978-0-312-04653-8

Library of Congress Cataloging-in-Publication Data

Messent, Peter B.

New readings of the American novel : narrative theory and its application / Peter Messent.

p. $\mathbf{c m}$.

ISBN 978-0-312-04653-8

1. American fiction-History and criticism. 2. Narration (Rhetoric) I. Title.

PS371.M47 1990

813.009-dc20

90-8042

CIP 


\section{Contents}

Acknowledgements

Introduction

vi

1 Speech Representation, Focalization and

Narration in The Great Gatsby

2 Time and Narrative: Faulkner's

The Sound and the Fury

3 Slippery Stuff: The Construction of

Character in The Sun Also Rises

4 The Dynamics of Reading: $A$ Lost Lady

5 The Portrait of a Lady and The House

of Mirth: A Barthesian Reading

162

6 The Clash of Language: Bakhtin and Huckleberry Finn

7 A Medley of Voices: Zora Neale Hurston's Their Eyes Were Watching God 


\section{Acknowledgements}

My interest in some of the materials developed here was first raised within the University of Nottingham Critical Theory Group. I would like to thank friends and colleagues within that group who offered helpful comments on individual sections of my manuscript: most especially - Elizabeth Boa, Diane Knight, Elaine Millard, and Douglas Tallack. I tested out some of the critical approaches represented here with my students. My thanks for their patience, cooperation, and ideas. Gavin Cologne-Brookes, working under my supervision toward his Ph.D. on William Styron's novels, discussed Bakhtin with me at length. I hope our conversations were as useful to him as they were to me.

My special thanks to two colleagues from my department whose help has been even more substantial. Richard King was ever-willing to read chapters and part-chapters for me in draft form. His good advice and warm encouragement were invaluable. So, too, were David Murray's. He read both separate sections of the book as I was proceeding, then the complete text at manuscript stage, and his comments were always incisive, always constructive. I consider myself privileged to have such colleagues and friends. With the help of all those named above, this book is much better than it would otherwise have been.

I also wish to thank Caroline Egar and Moira Eminton for the concern and care which she brought to this project; and Freda Duckitt, our departmental secretary, whose speed and accuracy in typing the book, despite other tasks at hand, was greatly appreciated. John Clements, the best of friends, provided the basketball, bourbon and good talk which gave 
much needed temporary relief in the throes of writing. William and Alice, my children, always special, showed real interest in what I was doing; both encouraged me and put up without complaint as I retreated yet again to work on this manuscript. My love to them. And also, of course, to Penny Craig to whom I owe a thousand thanks.

April, 1989

The author and publishers wish to thank the following who have kindly given permission for the use of copyright material: Basil Blackwell Ltd. for extracts from Narrative Discourse by Gerard Genette, 1986; The Bodley Head and Charles Scribner's Sons, an imprint of Macmillan Publishing Company for extracts from The Great Gatsby by F. Scott Fitzgerald. Copyright (C) 1925 by Charles Scribner's Sons; copyright renewed 1953 by Frances Scott Fitzgerald Lanahan; Georges Borchardt, Inc. and Hill and Wang, a division of Farrar, Straus \& Giroux, Inc. for extracts from S/Z: An Essay by Roland Barthes. Translation copyright (C) 1974 by Farrar Straus \& Giroux, Inc; Curtis Brown Ltd. and Random House, Inc. for extracts from The Sound and the Fury by William Faulkner. Copyright (C) 1929 and renewed 1957 by William Faulkner; Harper \& Row, Publishers, Inc. for extracts from Mules and Men by Zora Neale Hurston. Copyright (C) 1935 by Zora Neale Hurston; renewed 1963 by John C. Hurston; W. W. Norton \& Company, Inc. for extracts from The Portrait of a Lady by Henry James, A Norton Critical Edition, ed. Robert D. Bamberg. Copyright (C) 1975 by W. W. Norton \& Company, Inc; Charles Scribner's Sons, an imprint of Macmillan Publishing Company, for extracts from The Sun Also Rises By Ernest Hemingway. Copyright (C) 1926 by Charles Scribner's Sons; copyright (C) renewed 1953 by Ernest Hemingway; University of Texas Press for extracts from The Dialogic Imagination: Four Essays by M. M. Bakhtin, edited by Michael Holquist, translated by Caryl Emerson and Michael Holquist (C) 1981; Virago Press Ltd. and Harper \& Row, Publishers, Inc. for extracts from Their Eyes Were Watching God by Zora Neale Hurston. Copyright (C) 1935 by Zora Neale Hurston; renewed 1965 by John C. and Joel Hurston; and with Alfred A. Knopf, Inc. for extracts from $A$ Lost Lady by Willa Cather. Copyright (C) 1923 by Willa S. Cather; renewed 1951 
by Edith Lewis, Executrix and City Bank Farmers Trust Co.

Every effort has been made to trace all copyright holders, but if any have been inadvertently overlooked the publishers will be pleased to make the necessary arrangement at the first opportunity. 
To My Parents

John and Rosa Messent with all my love 